\title{
The Genetic Progress Realized in the Creation of Maize Hybrids at the A.R.D.S. Turda
}

\author{
Andrei VARGA ${ }^{1,2}$, Voichița HAȘ ${ }^{1}$, Roxana ȘUT ${ }^{1,2}$, Ana COPÂNDEAN ${ }^{1}$, Ioan HAȘ I, $^{1 *}$ \\ ${ }^{1}$ Agricultural Research and Development Station, 27 Agriculturii, CP 401100,Turda, Romania, \\ ${ }^{2}$ University of Agricultural Sciences and Veterinary Medicine Cluj-Napoca Calea Mănăştur no. 3-5, \\ 400372, Cluj-Napoca \\ * corresponding author: ioanhas@yahoo.com
}

Bulletin USAMV series Agriculture 72(1)/2015

Print ISSN 1843-5246; Electronic ISSN 1843-5386

DOI 10.15835/buasvmcn-agr: 11193

\begin{abstract}
This paper presents the study of the maize hybrids created at A.R.D.S. Turda that belongs to three vegetation period: very early, early and semi-early. The hybrids were studied in three experiences: PG 1, PG 2, PG 3 in 2011 and 2012. The climatic conditions of the 2011 and 2012 years were totally different for the maize crop: the year 2011 can be considered in terms of the rainfall as very favourable for the maize crop, while the year 2012 was a particularly dry year. There were studied hybrids from each group by comparison to the older released hybrid in order to observe the progress made in the breeding process for maize hybrids production, for stalking resistance and also precocity. For the characterization of the hybrids there were also followed other characters such as a thousand grain weight, silking data, physiological maturity date, the type of maturation, Ostrinia nubilalis attack resistance, hectolitre weight. Higher yield ability and better resistance to lodging was observed for the following hybrids included in the study: Turda SU 182 (very early hybrid), Turda Mold 188 (early hybrid), Turda Favorit and Turda Star (semi early hybrids). On the latest hybrids created at A.R.D.S. Turda it was noticed an improved resistance to lodging and stalking, but with a slight extension of the period of vegetation.
\end{abstract}

Keywords: hybrid, production capacity, physiological maturity

\section{INTRODUCTION}

Annually in Romania the maize crop occupies over 2,5 million hectares, this being the highest surface in the EU area, the cultivated areas being relative. The need to get higher productions in maize, but also constant productions, undertakes the scientific research to provide growers competitive maize hybrids and also seed with high genetic value.

The pedoclimatic conditions in the centre of the country require the cultivation of a wider range of hybrids, from the semi early hybrids to the group of very-early hybrids.

In the last 10 years (1991-2011) (Grecu et al., 2011) the climatic characteristics from the central and northern Romania changed by higher average temperature than the multiannual average of $9^{\circ} \mathrm{C}$
(1957-2010) as well as by the alternation between periods (May-June) with low temperatures and heavy rainfall up to flowering phenophase and the appearance of stigmata, followed by (July) high temperatures (above normal), soil drought and atmospheric drought especially during pollination and grain filling period. Also the climatic characteristics changed through the appearance of favourable conditions for breaking strains in autumn and cobs infected with Fusarium (rainfall, high relative humidity, high diurnal temperature amplitudes) (Haș, 2001).

The genetic progress in maize breeding has become a common practice for most breeding centres including ARDS Turda because it offers the opportunity to estimate the stage it reached and 
allows the taking of some decisions in the creation of hybrids in the future.

The grain yield undoubtedly remains a feature subjected to study (Russell, 1979; Căbulea and Grecu, 1982; Russell, 1986; Cosmin et al., 1987; Grecu and Căbulea, 1989).

Also attention has given to other important features as plant resistance to breaking and falling when harvesting and to the production elements of cobs and grains that contribute to the formation of the harvest.

\section{MATERIALS AND METHODS}

The biological material consisted in 12 hybrids of maize that were certified and created at A.R.D.S. Turda. The hybrids were experimented in three cultures PG 1, PG 2, PG 3 in two experimental years 2011 and 2012 (Tab. 1).

The hybrids were grouped based on the experiences of the growing season. The experimental plots were placed in the blocks method, in three replicates at a density of 70,000 plants / ha.

The experimental data was assessed using the analysis of variance specific to the experiences with one or two factors. The interpretation of the data was made using the program Polifact.

The production stability analysis was done on all three groups of precocity by interpreting the genotypic adaptability depending on the regression coefficient and the average production.
This paper compares the production capacity and production elements of maize hybrids homologated at ARDS Turda belonging to different groups of precocity

\section{RESULTS AND DISCUSSION}

The production capacity and some yield components differed being closed related with the vegetation period. The hybrids with a longer vegetation period (FAO 300-400) achieved higher productions values compared to the hybrids with lower vegetation period (PG-1: $5830 \mathrm{~kg} / \mathrm{ha}$; PG2: $6780 \mathrm{~kg} / \mathrm{ha}$; PG-3: $7242 \mathrm{~kg} / \mathrm{ha}$ ). In this group of hybrids in order to achieve the production of grains, the mass of a thousand grains, the yield and the better breaking plant resistance at harvest had a favourable contribution but also the grain moisture at harvest was higher.

After analyzing the data from table 2 we can see that the maize hybrids from very early group to early group recorded significant genetic progress, simultaneously, for all the three major features in the characterization of a hybrid (grain yield, earliness and resistance to breaking strains). Particularly the SU Turda 182 stands out, by exceeding the control hybrid Turda 200 in the two years of experimentation, both in their production capacity and also in the other two characteristics observed, as reflected by the selection index $109 \% / 2011$ and $127 \% / 2012$.

In 2012, the SU 182 Turda hybrid significantly exceeded the production of the control hybrid

Tab. 1. The hybrids taken under study

\begin{tabular}{cccc}
\hline The experience & Hybrid & Type of hybrid & $\begin{array}{c}\text { Year oh } \\
\text { certification }\end{array}$ \\
\hline \multirow{4}{*}{ PG 1 } & Turda 200 (control) & Double & 1976 \\
\cline { 2 - 4 } & Turda 100 & Double & 1979 \\
\cline { 2 - 4 } & Turda SU 181 & Simple & 2000 \\
\cline { 2 - 4 } & Turda SU 182 & Simple & 2000 \\
\cline { 2 - 4 } PG 2 & Elan (control) & Trilinear & 1992 \\
\cline { 2 - 4 } & Turda Mold 188 & Trilinear & 2001 \\
\cline { 2 - 4 } & Turda 165 & Trilinear & 2002 \\
\cline { 2 - 4 } & Turda 145 & Trilinear & 2004 \\
\cline { 2 - 4 } & Saturn (control) & Simple & 1994 \\
\cline { 2 - 4 } PG 3 & Turda 201 & Trilinear & 2002 \\
& Turda Favorit & Simple & 2001 \\
\cline { 2 - 4 } & Turda Star & Trilinear & 2005 \\
\hline
\end{tabular}


with $26 \%$ which highlights the stability of this hybrid production, even in drought conditions. The simple hybrid Turda SU 181 has achieved a superior production compared with the control, increasing by 1\% / 2011 and 4\% / 2012 even though it is an early hybrid.

The early hybrids stood out trough the high grain yield compared to the hybrids with shorter vegetation period (Tab. 3.). Of the early maize

Tab. 2. Very early and early hybrids FAO 100-230

\begin{tabular}{|c|c|c|c|c|c|c|c|c|}
\hline \multirow{2}{*}{ Hybrid } & \multirow{2}{*}{$\begin{array}{c}\text { Year of } \\
\text { homologation }\end{array}$} & \multicolumn{2}{|c|}{ Grain yield } & \multicolumn{2}{|c|}{$\begin{array}{l}\text { Dry matter in the } \\
\text { grain at harvest }\end{array}$} & \multicolumn{2}{|c|}{$\begin{array}{c}\text { Unbroken } \\
\text { mature plants }\end{array}$} & \multirow{2}{*}{$\begin{array}{c}\text { Selection } \\
\text { Index }\end{array}$} \\
\hline & & $\mathrm{kg} / \mathrm{ha}$ & $\% \mathrm{Mt}$ & $\%$ & $\% \mathrm{Mt}$ & $\%$ & $\begin{array}{c}\% \\
\mathrm{Mt}\end{array}$ & \\
\hline \multicolumn{9}{|c|}{$\mathrm{PG}-1$, in year 2011} \\
\hline Turda 200Mt. & 1976 & 6449 & 100 & 81.0 & 100 & 80.5 & 100 & 100 \\
\hline Turda 100 & 1979 & 6069 & 94 & 84.4 & 104 & 79.0 & 98 & 96 \\
\hline Turda SU 181 & 2000 & 6509 & 101 & 80.7 & 100 & 95.6 & 119 & 119 \\
\hline Turda SU 182 & 2000 & 6631 & 103 & 81.5 & 101 & 84.9 & 105 & 109 \\
\hline \multicolumn{2}{|c|}{ Average } & 6415 & - & 81.9 & - & 85.0 & - & - \\
\hline \multicolumn{2}{|c|}{ DL 5\% } & 1069 & 16 & 9.6 & 12 & 16.2 & 23 & - \\
\hline \multicolumn{9}{|c|}{$\mathrm{PG}-1$, in year 2012} \\
\hline Turda $200 \mathrm{Mt}$. & 1976 & 5074 & 100 & 83.9 & 100 & 93.7 & 100 & 100 \\
\hline Turda 100 & 1979 & 5361 & 106 & 82.5 & $98^{\circ}$ & 70.5 & $75^{\circ o}$ & 78 \\
\hline Turda SU 181 & 2000 & 5287 & 104 & 84.9 & 101 & 87.3 & 93 & 98 \\
\hline Turda SU 182 & 2000 & 6373 & $126^{*}$ & 83.1 & $99^{\circ}$ & 95.9 & 102 & 127 \\
\hline Turda 165 & 2002 & 4124 & $81^{\circ}$ & 83.5 & 100 & 92.6 & 99 & 80 \\
\hline \multicolumn{2}{|c|}{ Average } & 5244 & - & 83.6 & - & 88.0 & - & - \\
\hline \multicolumn{2}{|c|}{ DL 5\% } & 1073 & 19 & 0.9 & 1.0 & 12.3 & 17 & - \\
\hline
\end{tabular}

Tab. 3. Early hybrids FAO 250-290

\begin{tabular}{|c|c|c|c|c|c|c|c|c|}
\hline \multirow{2}{*}{ Hybrid } & \multirow{2}{*}{$\begin{array}{c}\text { Year of } \\
\text { homologation }\end{array}$} & \multicolumn{2}{|c|}{ Grain yield } & \multicolumn{2}{|c|}{$\begin{array}{l}\text { Dry matter in the } \\
\text { grain at harvest }\end{array}$} & \multicolumn{2}{|c|}{$\begin{array}{c}\text { Unbroken } \\
\text { mature plants }\end{array}$} & \multirow{2}{*}{$\begin{array}{c}\begin{array}{c}\text { Selection } \\
\text { Index }\end{array} \\
\% \mathrm{Mt}\end{array}$} \\
\hline & & $\mathrm{kg} / \mathrm{ha}$ & $\% \mathrm{Mt}$ & $\%$ & $\% \mathrm{Mt}$ & $\%$ & $\begin{array}{l}\% \\
\mathrm{Mt}\end{array}$ & \\
\hline \multicolumn{9}{|c|}{ PG - 2, in year 2011} \\
\hline Elan & 1992 & 6877 & 100 & 79.4 & 100 & 97.4 & 100 & 100 \\
\hline Turda Mold 188 & 2001 & 8305 & $121^{* *}$ & 79.1 & 100 & 96.1 & 99 & 119 \\
\hline Turda 165 & 2002 & 7214 & 105 & 80.8 & 102 & 84.3 & 87 & 92 \\
\hline Turda 145 & 2004 & 8953 & $130 * *$ & 80.2 & 101 & 98.1 & 101 & 132 \\
\hline \multicolumn{2}{|c|}{ Average } & 7837 & - & 79.9 & - & 94.0 & - & - \\
\hline \multicolumn{2}{|c|}{ DL 5\% } & 1571 & 19 & 1.5 & 2 & 14.8 & 19 & - \\
\hline \multicolumn{9}{|c|}{$\mathrm{PG}-2$, in year 2012} \\
\hline Elan & 1992 & 5840 & 100 & 84.0 & 100 & 88.9 & 100 & 100 \\
\hline Turda Mold 188 & 2001 & 6348 & 109 & 84.4 & 100 & 91.7 & 103 & 113 \\
\hline Turda 165 & 2002 & 4760 & $82^{\circ}$ & 83.8 & 100 & 93.2 & 105 & 85 \\
\hline Turda 145 & 2004 & 5578 & 96 & 83.9 & 100 & 93.4 & 105 & 100 \\
\hline Turda 201 & 2002 & 6087 & 104 & 83.1 & 99 & 95.3 & 107 & 111 \\
\hline \multicolumn{2}{|c|}{ Average } & 5723 & - & 83.8 & - & 92.5 & - & - \\
\hline \multicolumn{2}{|c|}{ DL 5\%- } & 987 & 16 & 1.1 & 1 & 10.7 & 14 & - \\
\hline
\end{tabular}


hybrids Turda Mold 188 stood out trough grain yield in both experimental years 2011 and 2012 with a production increase significantly distinct to the control hybrid Elan. The hybrid Turda 145 was characterized through a high production capacity achieved in 2011, through which the hybrid significantly exceeded the control with a
$30 \%$. Also from the selection index point of view the hybrids Turda Mold 188 and Turda 145, in 2011 were superior to the control hybrid Elan with an increase of $19 \%$ respectively $32 \%$. In 2012 the hybrid Turda 201 stood out both through production capacity but also through plant resistance to breaking.

Tab. 4. Semi early hybrids FAO 300-390

\begin{tabular}{|c|c|c|c|c|c|c|c|c|}
\hline \multirow[t]{2}{*}{ Hybrid } & \multirow{2}{*}{$\begin{array}{c}\text { Year of } \\
\text { homologation }\end{array}$} & \multicolumn{2}{|c|}{ Grain yield } & \multicolumn{4}{|c|}{$\begin{array}{l}\text { Dry matter in the grain Unbroken mature } \\
\text { at harvest }\end{array}$} & \multirow{2}{*}{$\begin{array}{c}\text { Selection } \\
\text { Index } \\
\% \mathrm{Mt}\end{array}$} \\
\hline & & $\mathrm{kg} / \mathrm{ha}$ & $\% \mathrm{Mt}$ & $\%$ & $\% \mathrm{Mt}$ & $\%$ & $\% \mathrm{Mt}$ & \\
\hline \multicolumn{9}{|c|}{$\mathrm{PG}-3$, in year 2011} \\
\hline Saturn & 1994 & 8155 & 100 & 76.9 & 100 & 96.8 & 100 & 100 \\
\hline Turda 201 & 2002 & 6342 & $78^{\circ 0}$ & 79.0 & $103^{*}$ & 96.2 & 99 & 79 \\
\hline Turda Favorit & 2001 & 7430 & 91 & 76.7 & 100 & 93.7 & 97 & 88 \\
\hline Turda Star & 2005 & 7565 & 93 & 78.1 & $102^{*}$ & 96.2 & 99 & 94 \\
\hline \multicolumn{2}{|c|}{ Average } & 7373 & - & 77.7 & - & 95.7 & - & - \\
\hline \multicolumn{2}{|c|}{ DL $5 \%$} & 796 & 10 & 1.2 & 2 & 15.9 & 20 & - \\
\hline \multicolumn{9}{|c|}{$\mathrm{PG}-3$, in year 2012} \\
\hline Turda 201 & 2002 & 5376 & 100 & 83.0 & 100 & 97.1 & 100 & 100 \\
\hline Turda Favorit & 2001 & 7599 & $141^{* * *}$ & 80.3 & $97^{\text {oo }}$ & 87.7 & 90 & 124 \\
\hline Turda Star & 2005 & 7393 & $138^{* * *}$ & 82.3 & $99^{\circ}$ & 86.2 & 89 & 121 \\
\hline Turda 248 & 2012 & 6478 & $120 * *$ & 81.2 & $98^{\circ 0}$ & 94.9 & 98 & 115 \\
\hline Turda 332 & - & 8706 & $162^{* * *}$ & 82.2 & $99^{\circ}$ & 99.3 & 102 & 164 \\
\hline \multicolumn{2}{|c|}{ Average } & 7110 & & 81.8 & - & 93.0 & - & - \\
\hline \multicolumn{2}{|c|}{ DL $5 \%$} & 1014 & 14 & 0.6 & 1 & 10.2 & 13 & - \\
\hline
\end{tabular}

Tab. 5. Observations performed on the very early - early hybrids

\begin{tabular}{|c|c|c|c|c|c|c|c|c|}
\hline Hybrid & $\begin{array}{l}\text { Vegetative } \\
\text { vigour } \\
\text { notes* }\end{array}$ & $\begin{array}{c}\text { Plants attacked by } \\
\text { Ostrinia nubilalis } \\
\% \text { appearance of } \\
\text { stigmata }\end{array}$ & $\begin{array}{l}\text { physic } \\
\text { date }\end{array}$ & $\begin{array}{l}\text { DATA } \\
\text { iological m } \\
\text { The type } \\
\text { note }\end{array}$ & $\begin{array}{l}\text { urity } \\
\text { aging } \\
*\end{array}$ & $\begin{array}{c}\text { Efficiency } \\
\%\end{array}$ & $\begin{array}{l}\mathrm{MMB} \\
\mathrm{g}\end{array}$ & $\begin{array}{c}\text { Hectolitre } \\
\text { weight kg/ } \\
\text { hl }\end{array}$ \\
\hline \multicolumn{9}{|l|}{ PG -1 , in year 2011} \\
\hline Turda 200 & 8 & 47.8 & 07 & 24.08 & 6 & 80 & 268 & 64.9 \\
\hline Turda 100 & 8 & 49.9 & 07 & 21.08 & 6 & 80 & 252 & 66.6 \\
\hline 3. Turda SU 181 & 7 & 24.6 & 07 & 19.08 & 7 & 80 & 265 & 69.1 \\
\hline 4. Turda SU 182 & 6 & 44.5 & 07 & 23.08 & 7 & 77 & 258 & 63.1 \\
\hline $\begin{array}{l}\text { Average of } \\
\text { experience }\end{array}$ & 7.3 & 41.7 & - & - & - & 79 & 261 & 65.9 \\
\hline \multicolumn{9}{|l|}{$P G-1$, in year 2012} \\
\hline Turda 200 & 6 & 91.1 & .07 & 20.08 & 7 & 80 & 268 & 64.9 \\
\hline Turda 100 & 8 & 86.6 & .07 & 18.08 & 4 & 80 & 252 & 66.6 \\
\hline Turda SU 181 & 5 & 93.7 & .07 & 20.08 & 5 & 80 & 265 & 69.1 \\
\hline 4. Turda SU 182 & 6 & 94.4 & .07 & 22.08 & 5 & 77 & 258 & 63.1 \\
\hline 5. Turda 165 & 7 & 90.3 & .07 & 20.08 & 4 & 79 & 240 & 67.6 \\
\hline $\begin{array}{l}\text { Average of } \\
\text { experience }\end{array}$ & 6.4 & 91.2 & - & - & - & 79 & 256 & 66.3 \\
\hline
\end{tabular}


The production capacity for semi-early hybrids was higher than that of the hybrids with shorter vegetation period. From Table 4, we can observe the genetic progress achieved by the semi-early hybrids (tested in 2012) which was significantly superior to the control hybrid Turda 201.

For this group in particular the progress recorded in order to improve the production capacities (332 Turda, Turda Favorit, Star Turda, Turda 248), but with a slight increase in both grain moisture at harvest and plant susceptibility to breaking.

The observations made during the growing season revealed the influence of the year 2012, compared with 2011, regarding the percentage of affected plants by Ostrinia nubilalis pest for all three groups of hybrids (Tab. 5., Tab 6., Tab 7).

In the course of year 2011 the sensibility of the studied hybrids was in a close relationship with the vegetation period, the percentage of attacked plants varied from $29.4 \%$ in the case of the semi early hybrids, to $41.7 \%$ attacked plants in the case of the very early hybrids. The climatic conditions of 2012, which was considered a very dry year, given the lack of rainfall over four months (June to September), favoured pest attack Ostrinia nubilalis, which leaded to percentages of attacked plants over $90 \%$ in all three groups of hybrids.

The production quality analysis of the maize hybrids grains

The analysis of the chemical composition of the grain from the hybrids taken under study shows the presence of small differences between genotypes, regardless of the FAO group they belong to. The starch content shows average amplitudes between $69.9 \%$ for Turda 200 to $71.6 \%$ for Turda 201 (Table 8). The protein content varies between lower limits of $10.1 \%$ for Turda 165 and $10.7 \%$ for Turda 201 to slightly higher values of $11.5 \%$ for Turda 200 and Turda 248. The fat content was

Tab. 6. Observations performed on the early hybrids

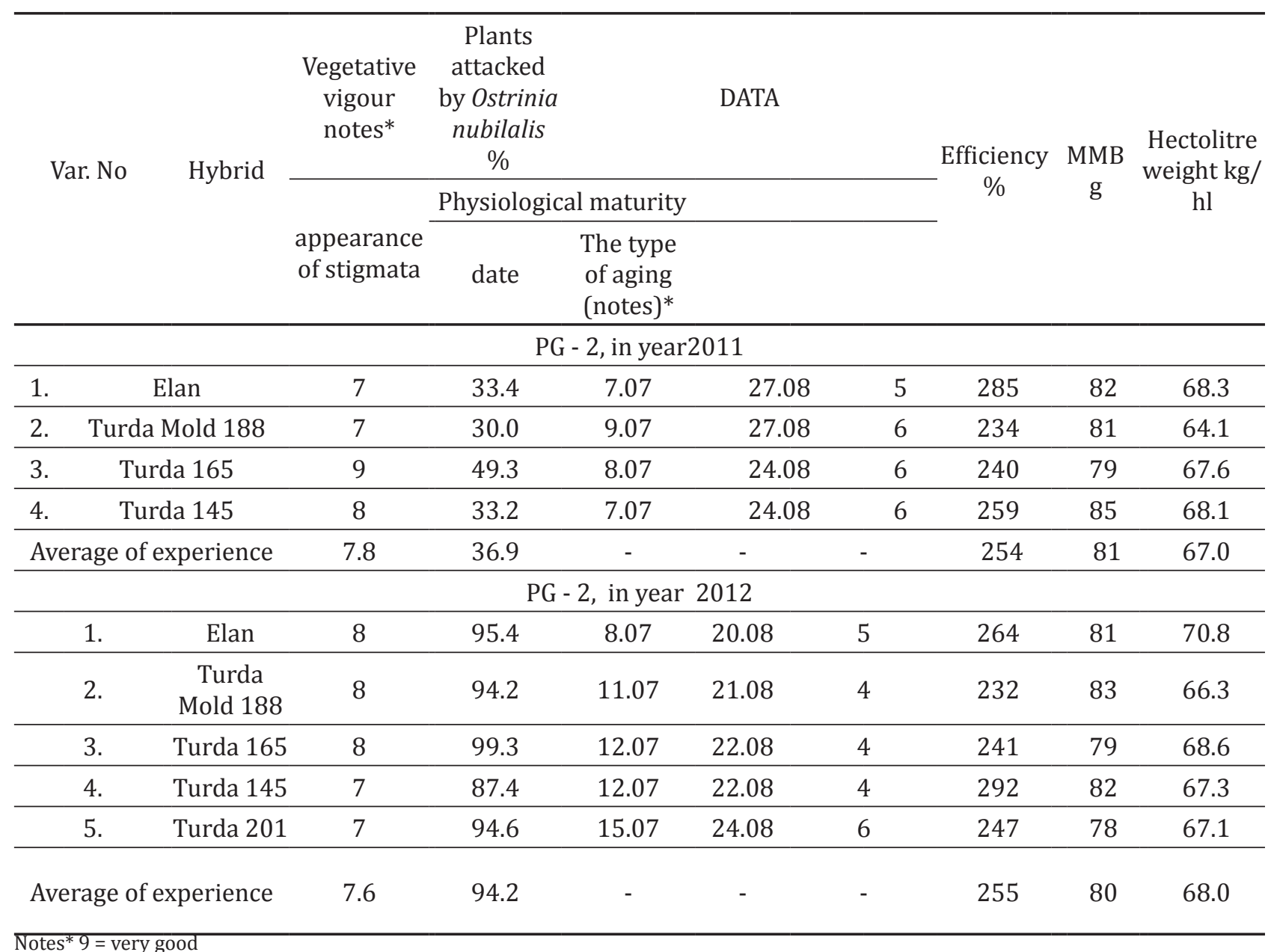


Tab. 7. Observations performed on the semi-early hybrids

\begin{tabular}{|c|c|c|c|c|c|c|c|c|c|}
\hline \multirow{3}{*}{$\begin{array}{l}\text { Var. } \\
\text { no }\end{array}$} & \multirow{3}{*}{ Hybrid } & \multirow{3}{*}{$\begin{array}{l}\text { Vegetative } \\
\text { vigour } \\
\text { notes* }\end{array}$} & \multirow{3}{*}{$\begin{array}{c}\text { Plants } \\
\text { attacked } \\
\text { by Ostrinia } \\
\text { nubilalis } \\
\%\end{array}$} & \multicolumn{3}{|c|}{ DATA } & \multirow{3}{*}{ Efficiency \% } & \multirow{3}{*}{$\begin{array}{l}\text { MMB } \\
\mathrm{g}\end{array}$} & \multirow{3}{*}{$\begin{array}{c}\text { Hectoliter } \\
\text { weight kg/hl }\end{array}$} \\
\hline & & & & \multirow{2}{*}{$\begin{array}{l}\text { Appearance of }- \\
\text { stigmata }\end{array}$} & \multicolumn{2}{|c|}{$\begin{array}{l}\text { Physiological } \\
\text { maturity }\end{array}$} & & & \\
\hline & & & & & Date & $\begin{array}{l}\text { The type } \\
\text { of aging } \\
\text { (notes)* }\end{array}$ & & & \\
\hline \multicolumn{10}{|c|}{$P G-3$, in year 2011} \\
\hline 1. & Saturn & 7 & 27.7 & 10.07 & 27.08 & 6 & 260 & 80 & 64.9 \\
\hline 2. & Turda 201 & 8 & 27.1 & 15.07 & 24.08 & 5 & 247 & 78 & 67.1 \\
\hline 3. & Turda Favorit & 7 & 34.1 & 17.07 & 28.08 & 6 & 241 & 81 & 65.9 \\
\hline 4. & Turda Star & 8 & 34.6 & 10.07 & 28.08 & 5 & 255 & 83 & 65.5 \\
\hline & $\begin{array}{l}\text { Average of } \\
\text { experience }\end{array}$ & 7.2 & 29.4 & - & - & - & 251 & 81 & 65.9 \\
\hline \multicolumn{10}{|c|}{ PG - 3, in year 2012} \\
\hline 1. & Turda 201 & 8 & 91.7 & 15.07 & 26.08 & 6 & 247 & 78 & 67.1 \\
\hline 2. & Turda Favorit & 7 & 97.3 & 11.07 & 23.08 & 6 & 243 & 81 & 65.9 \\
\hline 3. & Turda Star & 7 & 92.9 & 13.07 & 25.08 & 6 & 255 & 83 & 65.5 \\
\hline 4. & Turda 248 & 8 & 82.3 & 11.07 & 23.08 & 6 & 241 & 79 & 68.6 \\
\hline 5. & HST 131 & 8 & 85.6 & 13.07 & 25.08 & 6 & 292 & 82 & 67.3 \\
\hline & $\begin{array}{l}\text { Average of } \\
\text { experience }\end{array}$ & 7.6 & 90.0 & - & - & - & 256 & 81 & 66.9 \\
\hline
\end{tabular}

Tab. 8. Chemical composition of the grains of registered maize hybrids (the grains come from self pollinated cobs - 2012)

\begin{tabular}{|c|c|c|c|c|}
\hline \multirow{2}{*}{ Hybrid } & \multirow{2}{*}{$\begin{array}{l}\text { The humidity } \\
\text { of grains (\%) }\end{array}$} & \multicolumn{3}{|c|}{ The composition of the grains: } \\
\hline & & Starch (\%) & Proteins (\%) & Fats $(\%)$ \\
\hline \multicolumn{5}{|l|}{$P G-1$} \\
\hline Turda 200 & 14.6 & 69.9 & 11.5 & 4.2 \\
\hline Turda 100 & 14.5 & 70.7 & 11.0 & 4.0 \\
\hline Turda SU 181 & 13.5 & 70.9 & 10.6 & 4.2 \\
\hline Turda SU 182 & 13.9 & 70.7 & 10.9 & 4.0 \\
\hline Turda 165 & 14.1 & 70.9 & 10.7 & 4.1 \\
\hline \multicolumn{5}{|l|}{$P G-2$} \\
\hline Elan & 13.9 & 70.8 & 11.0 & 4.0 \\
\hline Turda Mold 188 & 14.2 & 70.9 & 10.4 & 4.3 \\
\hline Turda 145 & 14.5 & 70.6 & 10.6 & 4.5 \\
\hline Turda 165 & 14.0 & 71.2 & 10.1 & 4.2 \\
\hline Turda 201 & 14.3 & 71.3 & 10.1 & 4.2 \\
\hline \multicolumn{5}{|l|}{$P G-3$} \\
\hline Turda 201 & 13.7 & 70.9 & 10.7 & 4.0 \\
\hline Turda Favorit & 14.0 & 70.6 & 11.4 & 3.8 \\
\hline Turda Star & 13.6 & 70.5 & 11.2 & 4.0 \\
\hline Turda 248 & 14.1 & 70.1 & 11.5 & 4.2 \\
\hline Turda 332 & 14.0 & 71.0 & 10.7 & 3.9 \\
\hline
\end{tabular}


recorded between $3.8 \%$ for Turda Favorit and $4.5 \%$ for Turda 145 .

Figure 1 presents five very early maize hybrids classified by grain yield / ha and the regression coefficient. Therefore the hybrid Turda SU 182 from the third quadrant associates the value of the high average production to the subunit values of the regression. It is expected that the hybrid in the frame to perform well in a wide range of environmental conditions.

Finlay KW, Wilkinson GM (1963).

In the figure 2 are presented the five early hybrids studied, which by the grain yield $\mathrm{kg} / \mathrm{ha}$ and the regression coefficient were grouped in 3 of

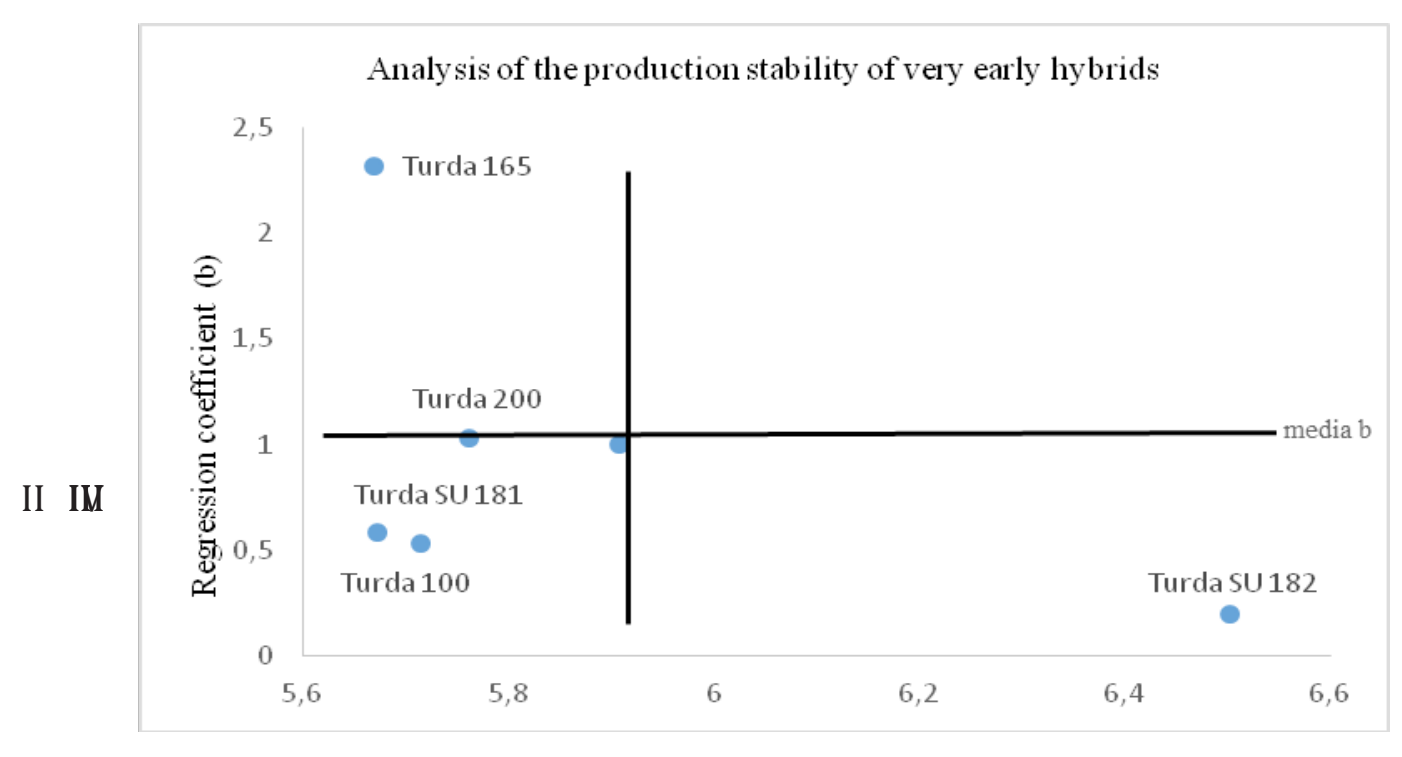

Fig. 1. The relationship between the grain yield $(\mathrm{kg} / \mathrm{ha})$ at 5 very early certified hybrids $\mathrm{x} 2$ experimental years (2011-2012) and the regression coefficient between the average and each hybrid

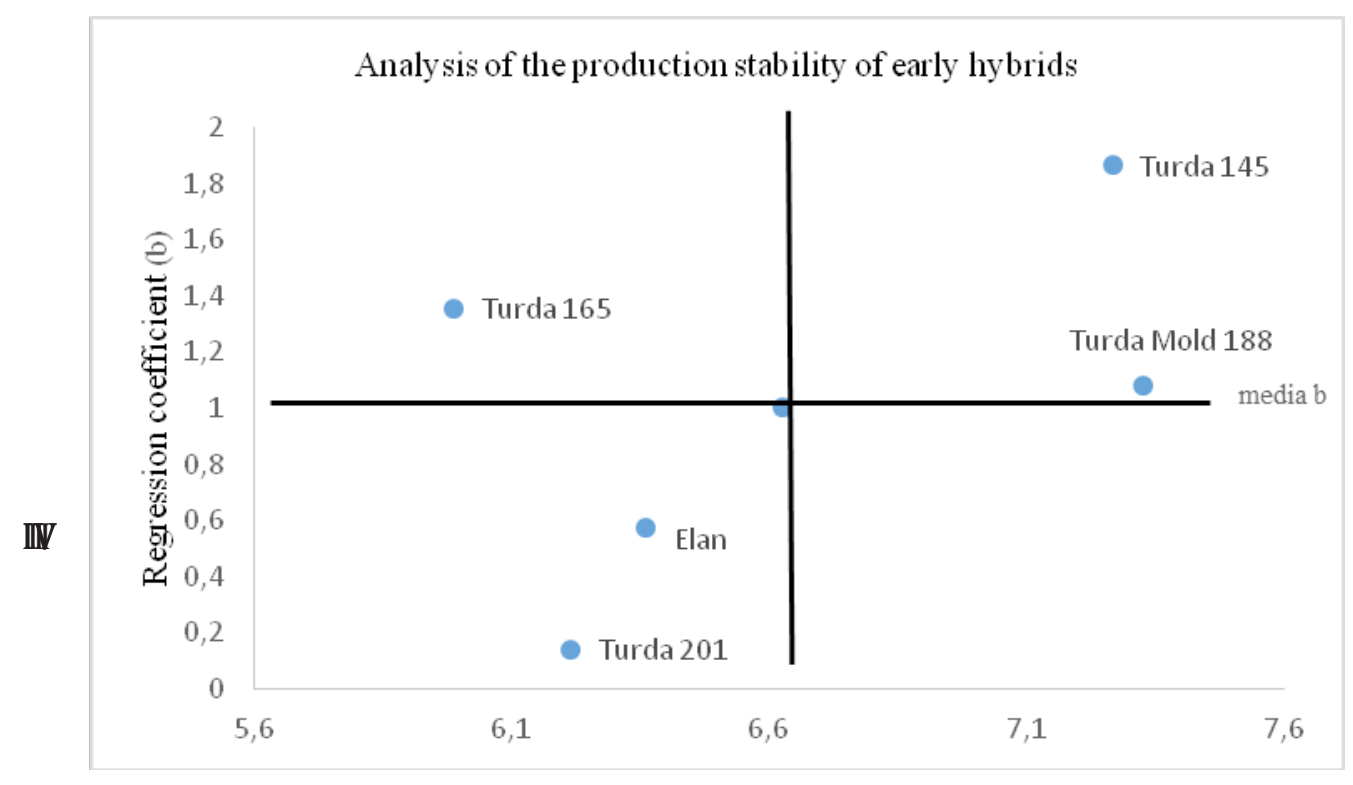

Fig. 2. The relationship between the grain yield ( $\mathrm{kg} / \mathrm{ha}$ ) of the 5 early certified hybrids $\mathrm{x} 2$ experimental years (2011-2012) and the regression coefficient between the average and each hybrid Finlay KW, Wilkinson GM (1963). 


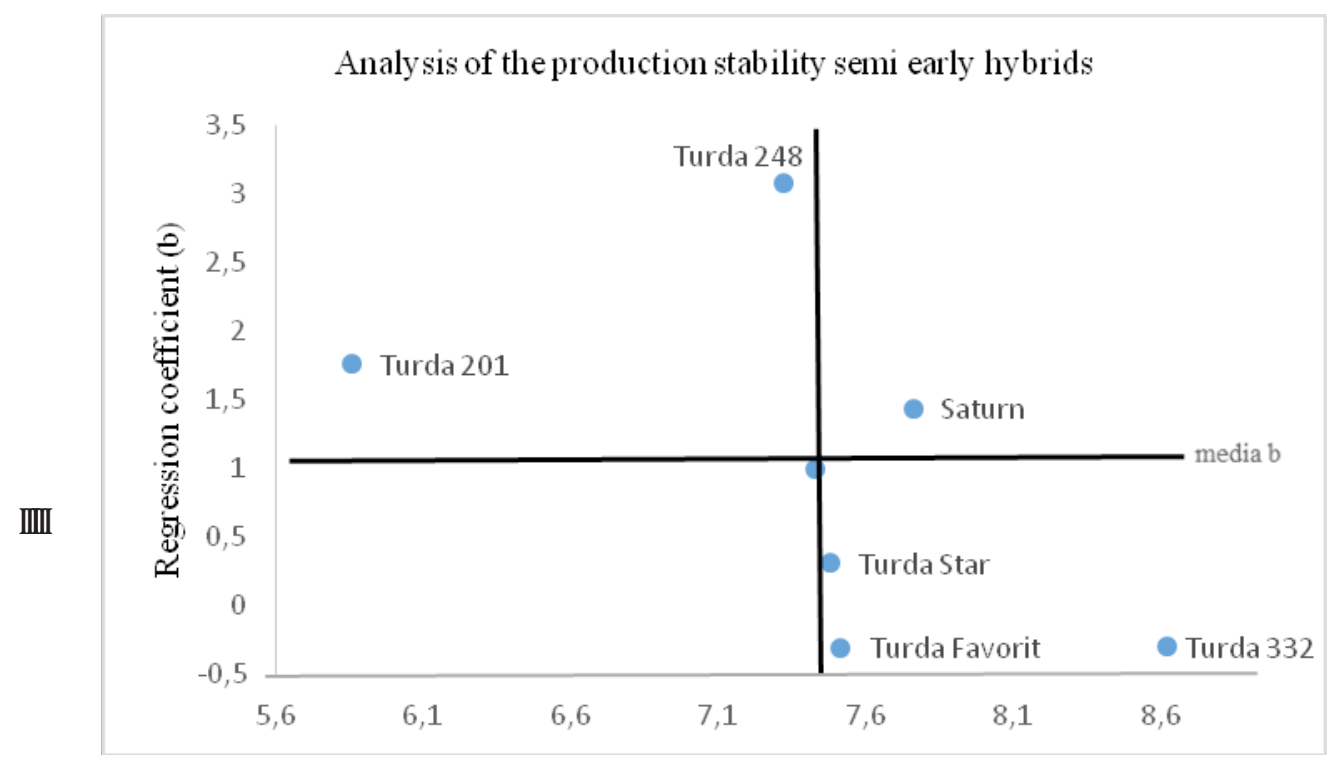

Fig. 3. The relationship between the grain yield (kg/ha) at 6 semi early certified hybrids $x 2$ experimental years (2011-2012) and the regression coefficient between the average and each hybrid. Finlay KW, Wilkinson GM (1963).

the 4 quadrants of the graph. Thereby it is observed a total lack of hybrids in quadrant III, meaning those that associate the production superior to the average value with the subunit values of the regression coefficient. Only two hybrids in this group had above average yields (Turda 145, Turda Mold 188), and therefore achieving high yields in the case of these hybrids depends on the achievement of optimal culture conditions.

Figure 3 presents six semi-early hybrids studied regarding the grain yield $\mathrm{kg} / \mathrm{ha}$ and the regression coefficient. Thus, the hybrids Turda Star, Turda Favorit and Turda 332 associate high average values of the production with the subunit values of the regression. It is expected that these hybrids to be efficient or to have a better performance in a wide range of environmental conditions. The Saturn hybrid although give a production higher to the average, with above unit " $b$ " values this hybrid will perform well only under favourable conditions.

\section{CONCLUSIONS}

The pedoclimatic conditions of the west area of the Transylvanian Plain (micro area Turda Plain Turda) are favourable to grow early and semi-early maize hybrids.

The climatic conditions of the years 2011 and 2012 were very different for maize culture.

Among the hybrids created at ARDS Turda in the last period, the best results were recorded for these hybrids:

Turda SU 182 from the very early hybrids group, whose production was superior to the control hybrid Turda 200, with 103\% in 2011 and $126 \%$ in 2012;

Turda Mold 188 exceeded the production of Elan hybrid with 121\% in 2011 and 109\% in 2012;

Turda Favorit and Turda Star achieved average yields, on the two years of experimentation, that exceeded the control hybrid Turda 201;

In the case of the hybrids create recently at ARDS it is observed an improvement in their resistance to lodging and breaking;

The analysis of the production stability shows that the Turda SU 182 hybrid, besides his higher production, even higher than the control hybrid 
Turda 200 also has good production stability in all environmental conditions.

ThehybridsTurdaStar,TurdaFavoritandTurda 332 have significantly higher yields compared to the control Turda 201 and these productions are also stable in various environmental conditions.

\section{REFERENCES}

1. Căbulea I, Grecu C (1982). 1982 - 25 ani de ameliorare a porumbului hibrid la Stațiunea deCercetări Agricole Turda; Contribuții ale cercetării științifice la dezvoltarea agriculturii. Red.Prop.Tehn.Agr., București.

2. Cosmin O, Bica N, Sarca TR, Ciocazanu I, Restea T (1987) Evaluarea progresului genetic în

3. ameliorarea porumbului. An.ICCPT Fundulea

4. Finlay KW, Wilkinson GM (1963). The analysis of adaptability in plant breeding programme.

5. Aust. J. Agric. Res. 14:742-754.
6. Grecu C, Căbulea I (1989). Hibrizi timpurii de porumb creați la SCA Turda în colaborare cu

7. Institutul de Cercetări pt. Cultura Cerealelor din Bernburg (R.D Germană). AN.ICCPT 57:61-70

8. Grecu C, Ignea M, Copândean Ana (2011). Evoluția regimului termic și pluviometric la Turda

9. în perioada 1957-2010 Agricultura Transilvană - Cultura plantelor de câmp. Buletin informative14:12-18.

10. Haș I (2001). Priorități în ameliorarea hibrizilor de porumb timpurii, Probl. genet. teor.aplic., 33(1-2):1-25.

11. Russel WA (1979).Comparative performance of maize hybrids representing different areas of

12. maize breeding. Proceding of 29th Annual Corn and Sorghum Research Conference, American Seed Trade Association.

13. Russel WA (1986) Agronomic performance of maize cultivars representing different areas of maize breeding. Maydica, XXIX. 
